\title{
THE PRODUCTION AND PROPERTIES OF COCONUT STEM CHARCOAL IN THAILAND
}

\author{
J. Dootson, Peyanoot Naka, Maliwan Rattanapruk \\ and Panit Ngangoranatigar ${ }^{1}$
}

\begin{abstract}
A programme of experimentation and training on the production of charcoal from coconut stems in transportable metal k.ilns was carried out. Comparisons were made between different timber densities, preparation methods and kiln loading systems. Other timber sources and traditional kilns were used. The highest density coconut wood produced the best charcoal and extensive preparation was found to be necessary. Local clay kilns produced excellent charcoal, but were slow and needed considerable fuel. Coconut stem charcoal. production was markedly different from carbonisation of wood from dicotyledonous trees.

The charcoal produced was found to have similar calorific value to that from other woods, but was faster-burning and easier to ignite. Content of volatile matter was low and little ash was produced. The charcoal was often rather wet. A sample of consurners found that the charcoal was better than they had expected. The main complaint was the speed of burning.
\end{abstract}

\section{INTRODUCTION}

The replanting of senile coconut stands with improved varieties is a priority of the Coconut Development Project in Thailand. To reduce the Weed for farmer subsidies or long-term credit dependency; sources of alternative income in the replanting process are sought. It is hoped that this will induce the voluntary participation of small farmers in coconut replanting by minimising disruption of cash flow. Use of felled palm components is one of the methods for creating the necessary revenue. The stem and, to a lesser extent, the terminal bud are the most valuable parts of the felled tree and viable means of using the stem are obviously important. Felled palms, or those dead, in the field, should in any case be disposed of to remove poissible breeding sites for rhinoceros beetle species.

Much research has been devoted to the use of coconut poles and sawn coconut timber, which requires considerable capital investment, but comparatively little is known about the use of the stems for charcoal production. Little (1974) produced, coconut shell charcoal using mobile CUSAB kilns and modified oil drum kilns, but found that the low density of the charcoal produced limited its applications. Some was used as an alternative to coke in ships galleys, but in the absence of a major industrial outlet it was suggested that the charcoal be mainly used domestically, although, an admixture with a heavier charcoal would be excellent for the luxury barbecue market.

In rural Thailand charcoal is a major source of fuel, and the Royal Forestry Department in Thailand estimate an annual, consumption of 3.5 million tons. $85 \%$ of this total comes from miscellaneous forest trees and $14 \%$ is from mangrove. Most of the charcoal in the south of Thailand is from mangrove and this valuable natural resource is under considerable stress. Charcoal production is-a traditional rural craft with a high proportion of smallholders making small quantities themselves. If it could be demonstrated that coconut wood could be successfully converted to charcoal, and that it could be done by traditional means, reduced stress on mangrove and forest resources would be a further useful achievement.

As a part of the input by the Overseas Development Administration (ODA) of the British Government to the Coconut Development Project of the Department of Agriculture, within the Royal Thai Government Ministry of Agriculture and Cooperatives, the Overseas Development Natural. Resources Institute (ODNRI) donated material and personnel to work on charcoal. production. The section of ODNRI responsible for this work was at that time known as the Tropical Development Research Institute (TDRI) who provided the services of Mr. A.P. Harker, a biomass energy specialist from their Industrial Development Division. 2 TDRI designed transportable steel kilns, together with ancillary equipment, and funds for local construction of a third kiln were provided (this cost 22,000 Baht or about US\$ 850). Mr. Harker's comprehensive experimental, programme and the training courses that he ran form the nucleus of this paper and much of the data quoted comes from his report (Harker, 1984).

\footnotetext{
${ }^{1}$ Agronomist, ODA Coconut Development Project: Processing Technologist, Coconut Specialist and Agronomist, Royal Thai Government Department of Agriculture; respectively.
} 
No attempt is made to describe the construction and general use of the transportable metal kilns as this is given in great detail elsewhere (Whitehead, 1980; Paddon and Harker, 1980). The use of transportable kilns was considered particularly relevant in coconut replanting schemes as they may be taken to the wood source, this being especially significant with heavy timber sources such as fresh coconut stem.

\section{WOOD PREPARATION}

The training courses were to be held at a single site, at the Chumphon Horticultural. Research Centre in southern Thailand, and therefore the coconut wood used was cut and taken to the location of the kilns, rather than taking the kilns to the farms themselves. This somewhat falsified the economics of production, Between 1st and $21^{\text {st }}$ December 1983 a number of overaged coconut palms were felled and cut into 1 meter sections using stihl chainsaws, on a total of 20 small farms. The farmers were to be given charcoal in exchange and would be asked to evaluate it as a consumer survey after the experimental programme was completed. A total of 157 cubic meters of coconut wood was cut and subdivided into 3 sections, giving 54 cubic meters of butt wood, 55 cubic meters from the mid-section of the stem and 48 cubic meters from the top of the stem.

Costs of wood preparation are given in Table 1. It should be noted that the loading and diese, 1 fuel costs would not apply in normal kiln operation, and this transport component of 5,743.05 Baht should be deducted in calculating the economics of on farm use of the kilns. Similarly the total labour cost would be negligible if smallholder opportunity labour was used as opposed to daily-paid workers. No adjustment is, however, made for capital items.

The wood was stacked, according to the stem section, in cross-layered piles of approximately 1 cubic metre, in the open. Butt sections in excess of $30 \mathrm{~cm}$ diameter were split once longitudinally. Stacking of the timber in the round was, completed by $27^{\text {th }}$ December 1983 in anticipation of the starting date for charcoal production on $7^{\text {th }}$ February 1984. The time lag was considered long enough for sufficient moisture to have been lost to enhance the efficiency of charcoal production, especially as the stacking period coincided with the start of the dry season in Thailand. It was found that the unsplit coconut timber released virtually no moisture when stacked, as a result of the peculiar vascular structure of the monocotyledonous stem. This is shown in Table 2.

Kiln loading and early experimental work showed that unsplit logs 1 metre in length were unwieldy, filled the available space inefficiently and carbonised poorly with a high yield of brands and ash remaining at the end of the run. The unsplit logs also did not release water sufficiently quickly and it was clear that they could not be used successfully for charcoal production. Splitting 1 metre lengths also proved extremely difficult and butt sections could only be split using a chain saw with square set teeth. To facilitate splitting and also to more efficiently fill the kiln the logs were cross cut into lengths of from 30 to $50 \mathrm{~cm}$. It can be clearly seen in Table 3 that splitting was the single most important wood preparation operation and that quartering and pith removal were additionally beneficial and it can be assumed that splitting prior to stacking would have been desirable. Further testing of this assumption is needed.

\section{KILN LOADING AND CHARCOAL PRODUCTION}

Kiln operations were as described elsewhere (Paddon and Harker, 1980) but with a few notable exceptions associated with high moisture content and low levels of organic compounds in the stern. The coconut stem charcoal. continued to emit steam when the optimurn amount of carbonisation had occurred and it was consequently extremely difficult to judge when the kiln should be closed down using the transparent blue colour of the smoke alone. Low organic content meant that there was no need to clean condensed tar deposits from the chimneys at any stage. When rubber wood was used, large quantities of tar were collected from a single run.

Transportable metal kilng are usually used with the wood packed horizontally within the kiln, whereas local termite mound kilns are normally packed vertically. The air flow in transportable metal kilns is vertical and packing horizontally means that the wood is across the flow.Vertical stacking would normally be expected to increase burning at the expense of charring. However, vertical packing did facilitate kiln filling and one run was surprisingly successful. When a traditional termite hill kiln was used, with vertical wood packing, a charcoal yield of $37.4 \%$ was obtained. This remarkable return was attained as the traditional method requires 10-12 times the quantity of kindling to produce the heat necessary for charring, whereas this heat is generated by the wood itself in metal kilns. Table 3 shows the returns from 16 runs and cortributing conditions of wood preparation and kiln use. 
Table 1: Coconut Stem Preparation Costs, Including Transporation

\begin{tabular}{|l|r|r|r|r|}
\hline & \multicolumn{1}{|c|}{ Felling } & Loading & Stacking & Splitting \\
\hline Mandays & 119 & 71 & 31 & 6 \\
Cost in Baht & $7,681.45$ & $4,543.05$ & $2,001.05$ & 387.30 \\
\hline
\end{tabular}

Assuming: 1 man day $=64.55$ Baht

(1US\$ = Approximately 25.5 Baht)

\begin{tabular}{|l|c|c|}
\hline & Diesel & Betrol \\
\hline Liters of fuel & 160 & 42 \\
Cost in Baht & 1,200 & 483 \\
\hline
\end{tabular}

Assuming : 1 litre of diesel $=7.50 \mathrm{Baht}$

1 litre of petrol $=11.50 \mathrm{Baht}$

Table 2: Moisture Content of Coconut Wood Compared with Rubber Wood

\begin{tabular}{|c|c|}
\hline Wood Type and Stem Section & $\%$ Moisture Content (Wet Basis) \\
\hline Fresh cut coconut (All sections) & 52.0 \\
\hline Stacked, unsplit coocnut (Butt) & 45.7 \\
\hline “ $\quad$ (Mid) & 47.3 \\
\hline “ $\quad$ (Top) & 57.9 \\
\hline Fresh cut rubber (All section) & 41.0 \\
\hline
\end{tabular}

A particular characteristic of metal kilns is the rapid time of charring, between 22 and 67 hours in the case of coconut wood, compared with 9 days in the termite mound kiln. Cooling was also rapid, between 16 and 41 hours compared with 4 days. This is largely a function of the excellent insulating properties of the clay kiln. This is dealt with in some detail in Mr. Harker's (1984) report. Thus the relatively poor percentage returns of charcoal from metal kilns was largely compensated for by the rapid conversion rate of large quantities of wood, with little need for external fuel gathering (most kindling was brands from previous runs with coconut husks and shells). Carbonisation and cooling times did not appear to correlate with other criteria of kiln use and quality.

\section{CHARACTERISTICS OF COCONUT WOOD CHARCOAL}

Much of the charcoal produced, especially from the top section of the stern and from the central pith, was of extremely small size, and passed through the mesh of a bag-filling sieve. It is unlikely that these charcoal fines could be used without some briquetting facility. It was clear that the best quality charcoal was made from the same high density butt wood that would preferentially be used for construction timber or furniture making, and that low density top wood or off-cuts from sawing operations would make charcoal of only limited usefulness, on its own. Bagged charcoal was very light, having average bag weights of $13.6 \mathrm{~kg}, 12 \mathrm{~kg}$ and $10.4 \mathrm{~kg}$ from butt, middle and top stem sections respectively, compared with $13.2 \mathrm{~kg}$ for mixed rubber wood charcoal.

Despite the generally poor physical characteristics of the charcoal, it proved to have extremely favourable properties when burned and compared well with more conventional wood charcoals. Stove testing was undertaken by Dr. Aroon Chomcharn of the Royal Forestry Department. A summary of results is given in Table 4, while in Table 5 comparisons are made between charcoal from coconut stem sections and from rubber wood and mangrove. Because of the experimental nature of the work, and use of coconut stems that were not thoroughly seasoned, there was a high degree of variability in results obtained. 
Table 3: Ranked Percentag Charcoal Yields from 16 Carbonising Runs

\begin{tabular}{|c|c|c|c|c|c|}
\hline $\begin{array}{c}\% \text { Charcoal } \\
\text { Yield }\end{array}$ & $\begin{array}{l}\text { Palm } \\
\text { Section }\end{array}$ & Length $(\mathrm{cm})$ & Spli/unsplit & Packing & Notes \\
\hline 37.4 & Butt & 100 & Split & Vert. & $\begin{array}{l}\text { From termite } \\
\text { Mound kiln }\end{array}$ \\
\hline 27.4 & Butt & 50 & Split & Horiz. & Split in quarters \\
\hline 27.0 & Mid & 30 & Split & Horiz. & $\begin{array}{l}\text { Split in quarters \& } \\
\text { Pith removed }\end{array}$ \\
\hline 24.8 & All & 40 & Split & Horiz. & Fresh cut wood \\
\hline 23.4 & Mid & 30 & Split & Vert. & \\
\hline 21.4 & All & 60 & Split & Horiz. & $\begin{array}{l}\text { Fresh cut rubber } \\
\text { wood }\end{array}$ \\
\hline 18.9 & Mid & 30 & Split & Horiz. & \\
\hline 18.8 & Top & 50 & Split & Horiz. & \\
\hline 18.0 & Butt & 50 & Split & Vert. & $\begin{array}{l}\text { Operated by local } \\
\text { Charcoal makers }\end{array}$ \\
\hline 17.7 & Mid & 30 & Split & Horiz. & \\
\hline 17.5 & Mid & 30 & Split & Horiz. & \\
\hline 16.7 & Butt & 50 & Split & Horiz. & \\
\hline 15.0 & Mid & 30 & Split & Horiz. & \\
\hline 10.9 & Top & 100 & unsplit & Horiz. & \\
\hline 8.1 & Top & 50 & unsplit & Vert. & \\
\hline 7.9 & Mid & 100 & unsplit & Horiz. & \\
\hline
\end{tabular}

Table 4: Properties of Charcoal from Different Sections of Coconut Stem

\begin{tabular}{|c|c|c|c|c|c|}
\hline $\begin{array}{c}\text { Stem } \\
\text { Section }\end{array}$ & $\begin{array}{l}\text { Calorific Value } \\
\text { Value }(\mathrm{MJ} / \mathrm{Kg})\end{array}$ & $\begin{array}{l}\% \text { Ash } \\
\text { content }\end{array}$ & $\begin{array}{l}\text { Total \% } \\
\text { Volatile }\end{array}$ & $\begin{array}{c}\text { Moisture } \\
\text { Content \% }\end{array}$ & $\begin{array}{c}\text { Fixed carbon } \\
\%\end{array}$ \\
\hline $\begin{array}{l}\text { Butt } \\
\text { (range) }\end{array}$ & $\begin{array}{r}31.8 \\
(30.7-32.7)\end{array}$ & $\begin{array}{r}2.5 \\
(2.2-2.9)\end{array}$ & $\begin{array}{r}17.3 \\
(8.9-26.6)\end{array}$ & $\begin{array}{r}3.0 \\
(2.1-4.2)\end{array}$ & $\begin{array}{r}80.2 \\
(71.2-88.7)\end{array}$ \\
\hline $\begin{array}{l}\text { Middle } \\
\text { (range) }\end{array}$ & $\begin{array}{r}31.6 \\
(29.7-33.8)\end{array}$ & $\begin{array}{r}2.8 \\
(1.8-4.1)\end{array}$ & $\begin{array}{r}18.4 \\
(7.2-31.6)\end{array}$ & $\begin{array}{r}5.5 \\
(4.5-8.4)\end{array}$ & $\begin{array}{r}78.8 \\
(65.9-89.4)\end{array}$ \\
\hline $\begin{array}{l}\text { Top } \\
\text { (range) }\end{array}$ & $\begin{array}{r}31.1 \\
(30.4-31.6)\end{array}$ & $\begin{array}{r}4.1 \\
(3.6-5.2)\end{array}$ & $\begin{array}{r}16.8 \\
(14.1-19.9)\end{array}$ & $\begin{array}{r}5.0 \\
(3.1-7.3)\end{array}$ & $\begin{array}{r}79.1 \\
(76.5-82.3)\end{array}$ \\
\hline $\begin{array}{l}\text { Fresh coconut } \\
\text { all sections }\end{array}$ & 32.5 & 2.0 & 21.4 & 3.5 & 76.6 \\
\hline $\begin{array}{l}\text { Butt wood used in } \\
\text { termited mound }\end{array}$ & 33.6 & 2.9 & 10.9 & 2.2 & 86.2 \\
\hline $\begin{array}{l}\text { Rubber wood } \\
\text { all sections }\end{array}$ & 31.5 & 2.6 & 24.3 & 2.6 & 73.1 \\
\hline
\end{tabular}

All values expressed as wet basis except for calorific value. 
Calorific values were similar to rubber wood charcoal from all stem sections though fixed carbon was usually higher from coconut, especially from the lower parts of the stem. Content of volatile compounds was usually extremely low and the charcoal consequently burned with little smoke. Ash contents were low in the charcoal from lower stem sections, but rather too high when the wood from the top section was used. This was often accompanied by a high moisture content.

All the coconut wood charcoal was extremely easy to ignite and burning was very rapid. Surprisingly the heat utilization efficiency of all stem sections was greater than for mangrove charcoal. Thus the only major drawback in using coconut wood charcoal as a fuel source was the high speed of burning which. was not suited to local cooking stoves, requiring frequent replenishment and resulting in excessive ash accumulation.

Table 5: Results of Stove Testing Comparison Trials Between Coconut, Rubber and Mangrove Wood Charcoal

\begin{tabular}{|l|c|c|c|c|}
\hline \multicolumn{1}{|c|}{$\begin{array}{c}\text { Charcoal } \\
\text { Source }\end{array}$} & $\begin{array}{c}\text { Minutes to } \\
\text { Ignite }\end{array}$ & $\begin{array}{c}\text { Minutes to boil } \\
\text { 3.7 kg of water }\end{array}$ & $\begin{array}{c}\text { Water boiled } \\
\text { Divided by fueld } \\
\text { used }\end{array}$ & $\begin{array}{c}\text { \%Heat utilization } \\
\text { Efficiency }\end{array}$ \\
\hline Mangrove & 6 & 18.8 & 2.05 & 28.19 \\
Rubber & 5 & 13.4 & 2.33 & 26.21 \\
Coconut butt & 3 & 13.7 & 2.8 & 31.37 \\
Coconut middle & 3 & 14.3 & 2.49 & 29.31 \\
Coconut top & 3 & 14.3 & 2.4 & 28.23 \\
\hline
\end{tabular}

\section{CONSUMER SURVEY}

The 20 farm families who had donated senile palms to the research project received a number of bags of charcoal and agreed to answer a series of 13 questions about their coconuts, their own charcoal making experience and opinions of the coconut wood charcoal they were, given. This is summarized in Appendix 1 for convenience. The general indications from this survey were that there were rarely sufficient palms on any one farm for large scale charcoal. making and there was little enthusiasm among the farmers for replanting in the absence of a real value for each palm stem. Most farmers would leave dead palms either standing or felled to rot, providing numerous breeding sites for rhinoceros beetle infestation. The farmers seemed unaware that this was a real danger. All farmers considered that underplanting of senile palms was preferable to clear felling and replanting because of the continued income from the old palms.

In addition to this survey a small number of local restaurant owners were asked to test samples of the coconut wood charcoal. They felt that fastburning and frequent need for replenishment were undesirable characteristics. Local charcoal merchants were not able to give a real value in the absence of large quantities for sale but felt that they would be able to sell butt and mid-section charcoal for about 2 Baht per kilogram, a similar price as for low-density conventional wood charcoal and less than the 3 or 4 Baht that was the price quoted for mangrove charcoal.

\section{CONCLUSIONS}

It was satisfactorily shown that coconut wood could be converted into charcoal using both mobile steel kilns and local methods, however, there is considerable doubt, expressed especially in Mr. Harker's report, that coconut wood can be converted economically. Even if the transport component is reduced through the mobility of the kiln, the labour involved in sawing and splitting is much greater than for woods obtained from dicotyledons. Also the most acceptable charcoal comes from the high density butt and mid-sections which are best suited for sawing. The possibility of using those parts which are wastes in sawing for conversion to charcoal has the drawback of producing poor quality charcoal which has few clearly identified end uses. It is therefore obvious that much need to be done to simplify manufacture and to create and identify potential end uses of the charcoal if this useful way of utilizing coconut stems in replanting projects or phytosanitory control schemes is to become more than an interesting oddity.

As a guide to those wh o might be interested in undertaking any further work on the production of coconut stem charcoal, this study has clearly defined a number of activities that must be incorporated in successful carbonisation and utilization of the end product. 
1. The fresh coconut stems must be split and cut to $50 \mathrm{~cm}$ lengths before seasoning. Ideally this splitting should be into quarters and central pith should be removed and reserved as kindling;

2. The kiln should be packed with stem sections laid horizontally;

3. As it is difficult to clearly define the end point of the run, a small amount of white discolouration in the otherwise blue smoke may be acceptable to avoid over-charring;

4. Good quality charcoal can only be made from denser stem sections with the upper part of the stem yielding a high percentage of dust and fines. This charcoal can only be used effectively when mixed with denser particles;

5. Identified end uses must take into account fast-burning characteristics. The luxury barbecue market has been identified but other uses in the producing countries themselves are needed. It is possible that forges would be able to use coconut woodcharcoal successfully;

6. Secondary processing techniques such as briquetting may prove necessary to adapt the charcoal to existing end uses.

\section{ACKNOWLEDGEMENTS}

This paper is presented with the permission of the Overseas Development Administration and of the Department of Agriculture of the Royal Thai Government.

The largely unsung yet immense contribution of ODNRI and especially of Mr. A.P. Harker cannot be over-estimated. Dr. Aroon Chomarn of the Royal Forestry Department of the Royal Thai Government is thanked for rapidly carrying out stove testing.

Finally, the contributions of all 32 participants involved in the charcoal training courses and all the small farmers who donated stems are gratefully acknowledged.

\section{REFERENCES}

Anon, 1983. A survey on Charcoal Production, Distribution and Consumption in Thailand. Final Report of the Forest Economics Sub-Division of the Royal Forestry Department, Bangkok.

Harker A. P., 1984, Training in the Use of TDRI Designed Transportable Steel Kilns for Coconut Stem Carbonisation in Thailand. TDRI Document Number R 1182 (A).

Little E. C. R., 1974. Unpublished Report to the UNIOP/ FAO Rhinoceros Beetle Project.

Paddon A. R. \& Harker A.P., 1980. Charcoal Production. Using a Transportable Metal Kiln. TPI Rural Technology Guide Number 12.

Whitehead W. D. J., 1980. The Construction of a Transportable Charcoal Kiln. TPI Rural Technology Guide Number 13. 
Results of a consumer survey of 20 farm families who donated coconut stems and received charcoal in return.

1. Area of coconuts farmed?

11 families had less than 1 hectare of coconuts

4 families had between 1 and 2 hectares of coconuts.

4 families had between 2 and 3 hectares of coconuts.

1 family had more than 3 hectares of coconuts.

2. Area of Coconuts Needing Replanting and When?

17 families intended to replant.

2.4 hectares needed replanting in 2-3 years.

0.48 hectares were in need of replanting in 5-6 years.

2.16 hectares needed replanting in 10 years

1.28 hectares needed replanting in 20 years

Some farmers wanted to plant sapodilla (Manilkara achras) instead. Most would underplant their existing palms and not fell until the replants were bearing.

3. Variety of Palm Currently Grown and Future Choice?

All grew the local Thai Tall

1 family would definitely replant using the same material, while the rest had not yet decided.

4. Number of Bags of Charcoal Received and from which runs?

Farmers received between 1 and 45 sacks of charcoal, proportional to the number of stems donated.

18 families received charcoal from all parts of the stem

1 family received only butt wood charcoal.

1 family received only mixed charcoal from all parts of the stem of freshly felled palms.

5. Farmers Comments on Using Coconut on the Charcoal, and Opinions on Variation Between Runs?

19 families were able to comment on the charcoal.

Mixed charcoal from the tresh cut palms was said to burn well with very little black smoke, and was very easy to ignite.

All the families receiving charcoal from all stem sections agreed that butt wood charcoal was better than from the middle part, which was in turn prefferable to the charcoal from the top of the stem. Top wood charcoal was not satisfactory as the stove had to be frequently reloaded because of the low density, and the quantity of ash was unacceptably high.

Some families mixed top wood charcoal with that from other sections and found it acceptable under the altered conditions.

6. Was any Charcoal Sold?

Only 1 farmer sold charcoal, at about $1.8 \mathrm{Baht} / \mathrm{kg}$. This compares well with the usual market price of 1.75-2 Baht $/ \mathrm{kg}$ for conventional wood charcoal, but is less than the 3-4 Baht $/ \mathrm{kg}$ usually paid for mangrove charcoal. The coconut wood charcoal. was used by all families for domestic cooking.

Most families had their own small pit kiln for making charcoal. 
7. Would they buy coconut wood charcoal and for how much?

Only 2 families ever bought charcoal, which was always from conventional sources. They could not give an opinion on future purchases as coconut charcoal was not available in the markets and therefore no price was fixed. All farm families agreed that the coconut Wood charcoal was of better quality and gave a far better result than they expected. $2 \mathrm{Baht} / \mathrm{kg}$ was the maximum that they felt they would be willing to pay for the charcoal.

8. Has any coconut been sawn for timber, and how was it sold?

14 families had never sawn any palms as they were all bearing.

6 farmers had sawn lightning dainage and nonbearing palms, but not for timber. They made a little coconut wood charcoal in traditional pit kilns but agreed that it was very labour intensive.

9. What is normally done with old palms?

14 families left dead palms standing to rot. 3 farmers felled lightning damaged and nonyielding palms and left them to rot on the ground. Only 3 families felled palms and used them. 2 made traditional charcoal and the other made furniture from the dense butt wood.

10. Would the farmer hire a mobile kiln for $500 \mathrm{Baht} / \mathrm{week}$ if the could make $500 \mathrm{~kg}$ of charcoal in that week, given that the wood was already prepared?

None of the farmers felt that they had enough coconuts that they would be prepared to fell to make enough charcoal. None of them had the necessary equipment for preparing large quantities of coconut wood.

1 farmer would hire a kiln to make conventional wood hire a kiln to make conventional wood charcoal as the labour for preparing large quantities of coconut wood.

1 farmer would hire a kiln to make conventional wood charcoal as the labour for preparation is much less.

11. Would the farmer sell the palm to a charcoal maker or log sawer, how much for and would they give the palms away in exchange for felling? All 20 families would sell old palms, but there is no demand and it is impossible to fix a price.

12. Does the farmer have an axe, access to a chainsaw and the use of a tractor and trailer?

All had an axe, and most had pit kilns. None had access to machinery except on hire at. high rates.

13. If the farmer could sell coconut stem charcoal would it encourage him to knock down old palms for replanting?

The farmers were unanimous that if they could sell palm charcoal at a profit, or attach any monetary value to felled palms it would provide them with incentive for replanting. 